\title{
UBC wt Allele
}

National Cancer Institute

\section{Source}

National Cancer Institute. UBC wt Allele. NCI Thesaurus. Code C52257.

Human UBC wild-type allele is located in the vicinity of 12 q24.3 and is approximately $3 \mathrm{~kb}$ in length. This allele, which encodes ubiquitin protein, is involved in the modulation of protein half-life. The allele is essential for the mediation of nonlysosomal protein processing. 